\title{
Mineralogic and Petrologic Investigation of Post-Test Core Samples from the Spent Fuel Test-Climax
}

\author{
F. J. Ryerson and J. Beiriger
}

Manuscript Date: February 1985

\begin{abstract}
DISCLAIMER
This report was prepared as an account of work sponwored by an asency of the United States Government. Neither the United States Government nor any agency thereof, nor any of their employees, makes any warranty, express or implied, or assumes any legal liability or responsibility for the accuracy, completeness, or usefulness of any information, apparatus, product, or process disclosed, or represents that its use would not infringe privately owned rights. Refercoce herein to any specific commercial product, procesa, or service by trade name, trademark, manufacturer, or otherwise does not necesuarily constitute or imply its endornement, reoommendation, or favoring by the United Stutes Government or any agency thereof. The viewa and opinions of suthors expresed herein do not necessarily state or reflect thowe of the United States Government or any asency thereof.
\end{abstract}

\section{LAWRENCE LIVERMORE LABORATORY University of California $\bullet$ Livermore, California $\bullet 94550$}




\section{Contents}

Abstract $\ldots \ldots \ldots \ldots \ldots \ldots \ldots \ldots \ldots \ldots \ldots \ldots \ldots \ldots \ldots \ldots \ldots \ldots \ldots \ldots \ldots \ldots \ldots \ldots \ldots$

Introduction $\ldots \ldots \ldots \ldots \ldots \ldots \ldots \ldots \ldots \ldots \ldots \ldots \ldots \ldots \ldots \ldots \ldots \ldots \ldots \ldots \ldots \ldots \ldots \ldots, 1$

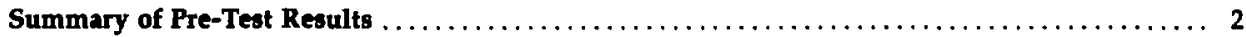

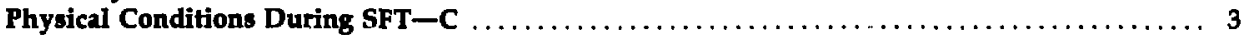

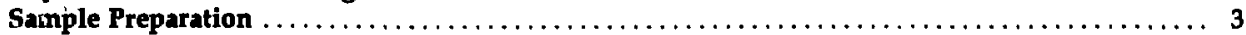

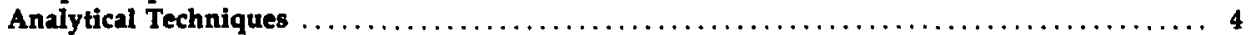

Fetrographic Analysis $\ldots \ldots \ldots \ldots \ldots \ldots \ldots \ldots \ldots \ldots \ldots \ldots \ldots \ldots \ldots \ldots \ldots \ldots \ldots \ldots \ldots \ldots, 4$

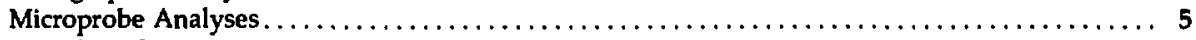

Post-Test Results $\ldots \ldots \ldots \ldots \ldots \ldots \ldots \ldots \ldots \ldots \ldots \ldots \ldots \ldots \ldots \ldots \ldots \ldots \ldots \ldots \ldots \ldots \ldots \ldots \ldots$

Modal Analyses $\ldots \ldots \ldots \ldots \ldots \ldots \ldots \ldots \ldots \ldots \ldots \ldots \ldots \ldots \ldots \ldots \ldots \ldots \ldots \ldots \ldots, \ldots \ldots \ldots$

Mineral Chemistry-Primary Phases $\ldots \ldots \ldots \ldots \ldots \ldots \ldots \ldots \ldots \ldots \ldots \ldots \ldots \ldots \ldots \ldots \ldots \ldots, 8$

Feldspars $\ldots \ldots \ldots \ldots \ldots \ldots \ldots \ldots \ldots \ldots \ldots \ldots \ldots \ldots \ldots \ldots \ldots \ldots \ldots \ldots \ldots \ldots$

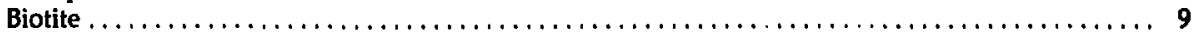

Mineral Chemistry -Alteration Phases $\ldots \ldots \ldots \ldots \ldots \ldots \ldots \ldots \ldots \ldots \ldots \ldots \ldots \ldots \ldots \ldots \ldots \ldots$

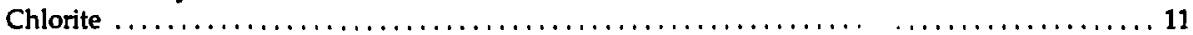

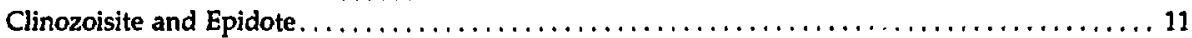

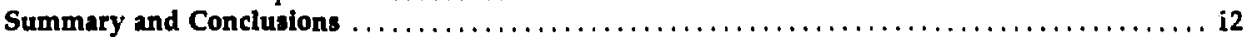

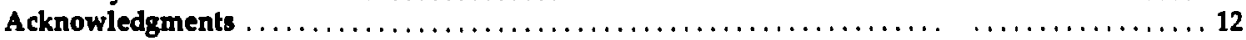

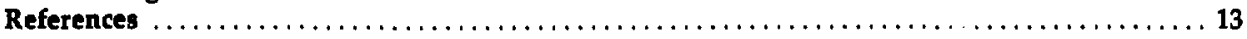




\title{
Mineralogic and Petrologic Investigations of Post-Test Core Samples from the Spent Fuel Test-Climax
}

\begin{abstract}
We have characterized a suite of samples taken subsequent to the end of the Spent Fuel Test-Climax by petrographic and microanalytical techniques and determined their mineral assemblage, modal properties, and mineral chemistry. The samples were obtained immediately adjacent to the canister borehole at a variety of depths and positions within the canister drift, as well as radially outward from each canister hole. This method of sampling allows variations in post-test mineralogic properties to be evaluated on the basis of (1) depth along a particular canister hole and (2) position within the canister drift, with respect to the heat and radiation sources, and with respect to the pre-test samples. In no case did we find any significant correlation between the mineralogical properties and variables listed above. In short, the Spent Fuel Test-Climax has produced no identifiable mineralogical response in the Climax quartz monzonite.
\end{abstract}

\section{Introduction}

The Spent Fuel Test-Climax (SFT-C) was conducted under the !echnical direction of the Lawrence Livermore National Laboratory as part of the U.S. Department of Energy's Nevada Nuclear Waste Storage Investigations. The major objective of the SFT $-C$ was to evaluate the technical feasibility of short-term emplacement and retrieval of spent reactor fuel assemblies at plausible repository depth in granitic rocks (Ramspott et al., 1979). A secondary goal was to evaluate the chemical and physical response of a typical granitic lithology to the thermal and radiation fields produced by the spent fuel assemblies. Because the granite (sensu lato) at Climax falls within the confines of crystalline rock (as defined by OCRD1, 1983), these results establish a starting point for further investigations of high-level waste storage in crystalline rock.

Data regarding changes in the mechanical properties of the Climax granite as a result of mining operations and canister emplacement, as well as infornation regarding physical conditions during the test, instrumentation, dosimetry, and metallurgical studies, are summarized in a series of technical interim reports (Carlson et al., 1980; Patrick et al., 1982, 1983, 1984). In this report we focus on mineralogical changes in the host granite as a result of the SFT $-\mathrm{C}$.

The mineralogy and petrology of pre-test samples from canister core holes 1 through 17 ( $\mathrm{CCH} 1-17)$ were presented in a previous report (Ryerson and Qualheim, 1983). In this report we present a similar set of data for post-test samples obtained from cores drilled adjacent to the intersection of the canister emplacement hole (CEH) and the initial canister core hole. Samples taken from this position experienced the most intense radiation and thermal histories within the canister drift, and their proximity to the previously studied $\mathrm{CCH}$ samples allows mineralogical changes produced by the SFT-C to be determined from comparison of pre- and post-test data sets. 


\section{Summary of Pre-Test Results}

The Climax Stock is a composite granitic pluton of Cretaceous age and is compused of an equigranular biotite grandiorite and a porphyritic biotite quartz monzonite that were intruded into Paleozoic carbonates (Maldonado, 1977). The tunnel complex used for the SFT-C lies entirely within the quartz monzonite. Previous investigations show that the quartz monzonite has experienced variable degrees of hydrothermal alteration by a water-rich fluid $\left[X\left(\mathrm{CO}_{2}\right)=0.018\right]$ at maximum temperature $\left(\sim 370^{\circ} \mathrm{C}\right)$ and pressure $(1 \mathrm{kbar})$ (Connolly, 1981; Ryerson and Qualheim, 1983).

The primary igneous quartz monzonite is a porphyritic rock composed of a groundmass of equant to subhedral grains of plagioclase, $K$ feldspar, quartz, and biotite ranging from 0.5 to $2.0 \mathrm{~mm}$ in diameter. The groundmass plagioclase is tabular and elongate and displays ubiquitous oscillatory zoning and polysynthetic twinning. The K-feldspars are untwinned, and the quartz grains often display undulatory extinction. K-feldspar, quarłz, and biotite are also present as phenocrysts ranging from 4 to $6 \mathrm{~mm}, 3$ to $15 \mathrm{~mm}$, and 1 $\mathrm{mm}$ in diameter, respectively. Titanite, zircon, apatite, and allanite are the primary igneous accessory phases and comprise less than 3 vol\% of the rock.

The average feldspar compositions are $\mathrm{Or}_{89.1}$ and $\mathrm{An}_{32.6}$ for $\mathrm{K}$-feldspar and plagioclase, respectively. Plagioclase compositions vary between $A n_{20}$ and $A n_{50}$ and $K$-feldspar varies between $\mathrm{Or}_{80}$ and $\mathrm{Or}_{98}$. The primary biotite composition is best expressed by the formula

$$
\mathrm{K}_{2}\left[\mathrm{Ti}_{0.4}(\mathrm{Fe}, \mathrm{Mg})_{4.8} \mathrm{Al}_{0.26}\right]\left[\mathrm{Al}_{2.4} \mathrm{Si}_{5.6}\right] \mathrm{O}_{50}(\mathrm{OH})_{4}
$$

Hydrothermal alteration is concentrated on biotite and plagioclase sites and is characterized by ubiquitous deuteric alteration and more intense alteration (as intense as potassic) localized along veins. The vein mineralogies ar 2 of two distinct types. The first type, known as barren, is composed of quartz with or without pyrite. Alteration zones adjacent to these veins are thin (5 $\mathrm{mm}$ ) and lack intense secondary mineralization. Calcite, in particular, is always missing from these veins. The second vein assemblage, known as fertile, is composed of quartz, calcite, pyrite, epidote, and apatite and may also contain some grains of muscovite, K-feldspar, and intensely altered plagioclase. The alteration zones adjacent to these veins may be up to $2 \mathrm{~cm}$ wide and show extensive secondary mineralization.
Plagioclase is altered to some combination of muscovite, calcite and epidote, and clinozoisite. Muscovite is the most common alteration mineral in both the deuterically altered rocks and within the localized alteration zones and is given by the formula

$$
\begin{gathered}
K_{2}\left[(\mathrm{Mg}, \mathrm{Fe})_{1.62} \mathrm{Al}_{2.92}\right]\left[\mathrm{Al}_{1.6} \mathrm{Si}_{6.4}\right] \mathrm{O}_{20}(\mathrm{OH})_{4} \\
-\mathrm{K}_{2} \mathrm{Al}_{4}\left(\mathrm{Al}_{2} \mathrm{Si}_{6}\right) \mathrm{O}_{20}(\mathrm{OH})_{4}
\end{gathered}
$$

where $\mathrm{Mg} /(\mathrm{Mg}-\mathrm{Fe})$ ranges between 0 and 1.0 . Muscovites found on plagioclase are lower in iron and magnesium than those on biotite. Epidote and clinozoisite, which are also found in both deuteric and localized alteration zones, display very complex zoning patterns ranging from pure $\mathrm{Ep}_{49}$ to $\mathrm{Ep}_{79}$ in a single grain. Calcite mineralization on plagioclase is restricted to alteration zones adjacent to fertile veins. Plagioclase adjacent to alteration phases is typically depleted in anorthite component relative to fresh plagioclase.

Biotite displays a wide variety of secondary mineralization, including, in order of increasing intensity, chlorite, epidote, muscovite, titanite, pyrite, calcite, and rutile. The most common assemblages are (1) biotite and chlorite, (2) biotite, chlorite, and epidote, and (3) biotite, chlorite, epidote, and titanite. The average chlorite composition is given by the formula

$$
(\mathrm{Fe}, \mathrm{Mg})_{8.8} \mathrm{Mn}_{0.2} \mathrm{Al}_{5.2} \mathrm{Si}_{5.6} \mathrm{O}_{20}(\mathrm{OH})_{16} \text {. }
$$

and the $\mathrm{Mg} /(\mathrm{Mg}-\mathrm{Fe})$ is 0.42 to 0.74 and slightly larger than that in the primary biotites. Epidote is given by the formula

$$
\mathrm{Ca}_{2}\left(\mathrm{Al}, \mathrm{Fe}^{3+}\right)_{3} \mathrm{Si}_{3} \mathrm{O}_{12}(\mathrm{OH})
$$

and varies between $\mathrm{Ep}_{68}$ to $\mathrm{Ep}_{8,6}$. Titanite and $\mathrm{py}$ rite are $\mathrm{CaTiSiO}_{5}$ and $\mathrm{FeS}_{2}$, respectively, and the average calcite composition is given by

$$
\mathrm{Ca}_{0.98} \mathrm{Mg}_{0.01} \mathrm{Fe}_{0.01} \mathrm{CO}_{3} \text {. }
$$

The alteration assemblages record the progressive loss of calcium from the plagioclase sites (depletion of anorthite component) to the biotite sites (presence of epidote) and the transfer of potassium, magnesium, and iron from the biotite sites to the plagioclase sites (formation of muscovite). In highly altered samples, the preferential loss of anorthite from the plagioclase during hy- 
drothermal alteration can lead to a bimodal distribution of plagioclase compositions with modes at $A n_{31}$ and $A n_{5}$. The latter refers to the altered plagioclase and is always spatially localized near alteration phases (e.g., muscovite, clinozoisite, and calcite).

In our previous study (Ryerson and Qualheim, 1983), we evaluated the chemical and petrographic variability of these samples with respect to position within any single $\mathrm{CCH}$ and within the canister dritt itself. We concluded that no intersample variation in mineral chemistry can be attributed to sample position. The same is true for all other petrographic features including mineral abundances. All intra- and intersample variations can be attributed to either primary igneous processes (e.g., mineral zoning, presences of phenocrysts) or secondary alteration processes (e.g., the presence or absence of either barren or fertile veins).

\section{Physical Conditions During SFT-C}

The 17-canister-hole array for the SFT-C contained both spent fuel canisters and electrical simulators. The spent fuel was in place between 2.5 and 5.5 YOC (years out of reactor core). Thermocouples at the canister, liner, $200 \mathrm{~m}$ into the rock, and $360 \mathrm{~m}$ into the rock measured the nearfield temperatures. Temperature-time-distance profiles were also calculated on the basis of the relevant thermal output and thermal characteristics of the liners, rock, etc. for all these positions plus the rockwall position; no thermocouple was placed at the rockwall. The agreement between calculated and measured temperatures for the five central canister holes is excellent. Although the calculations tend to overestimate temperatures in the distal holes as edge effects become more important, the disagreement at the midplane for the distal canister holes is still less than $5^{\circ} \mathrm{C}$ (Patrick et al., 1982).

Our post-test investigation focused on canister emplacement holes 1, 3, 4, and 9. CEH1, CEH3, and $\mathrm{CEH} 9$ contained spent fuel assemblies, and CEH4 contained an electrical simulator (Carlson et al,, 1980). We selected CEH4 so that any differences in mineralogical response due to heat vs heat and radiation could be recognized; CEH9 represents the center of the array and should have experienced the greatest time-integrated temperature. Maximum temperatures at the rockwall surface did not exceed $80^{\circ} \mathrm{C}$ for any of the CEHs and decreased approximately $15^{\circ} \mathrm{C}$ between the thermal maximum at $2.9 \mathrm{YOC}$ and canister removal at 5.4 YOC (Patrick et al., 1982,1984).

CEH1 contained water up to 3.0 YOC (Patrick et al., 1982); therefore, it afforded the greatest opportunity to observe hydrothermal effects, as well as the effects of radiolysis. The presence of water in the bottom of $\mathrm{CEH} 1$ buffered the canister temperature at $100^{\circ} \mathrm{C}$, compared to $120^{\circ} \mathrm{C}$ at the bottom of CEH9. However, the temperature measured $360 \mathrm{~mm}$ into the rock adjacent to the bottom of CEH1 at 3.1 YOC was less than $10^{\circ} \mathrm{C}$ cooler than that measured at the bottom of $\mathrm{CEH} 9$ at the same time (Patrick et al., 1982). Hence, for the purposes of this report, the $17 \mathrm{CEHs}$ can be considered an isothermal array.

\section{Sample Preparation}

Our method of selecting and preparing samples is shown in Fig. 1. The 6-in.-diam post-test core was obtained along a radius of the canister emplacement borehole, at the point of intersection with the pre-test borehole (the $\mathrm{CCH}$ was within the perimeter of the subsequently drilled canister emplacement borehole). Therefore, the pre-test $\mathrm{CCH}$ core and post-test core (PTC) provide a continuous sample radial to the canister emplacement borehole.

We logged the PTC and chose sampling regions that represented both areas of fresh unal- tered granite and areas intersected by heated and/ or open fractures and veins. Then we cut disks ( 8 to $25 \mathrm{~cm}$ thick) from the core in these areas and sectioned them along a radius of the emplacement hole, subsequently resectioning each semicircular disk parallel to the previous cut to obtain a slab. We then cut this slab parallei to the axis of the emplacement borehole to obtain a number of smaller slabs from which we prepared thin sections. At each depth, sample $A$ is closest to the wall of the canister borehole and sample $F$ is farthest from the hole. To assure correct orientation 


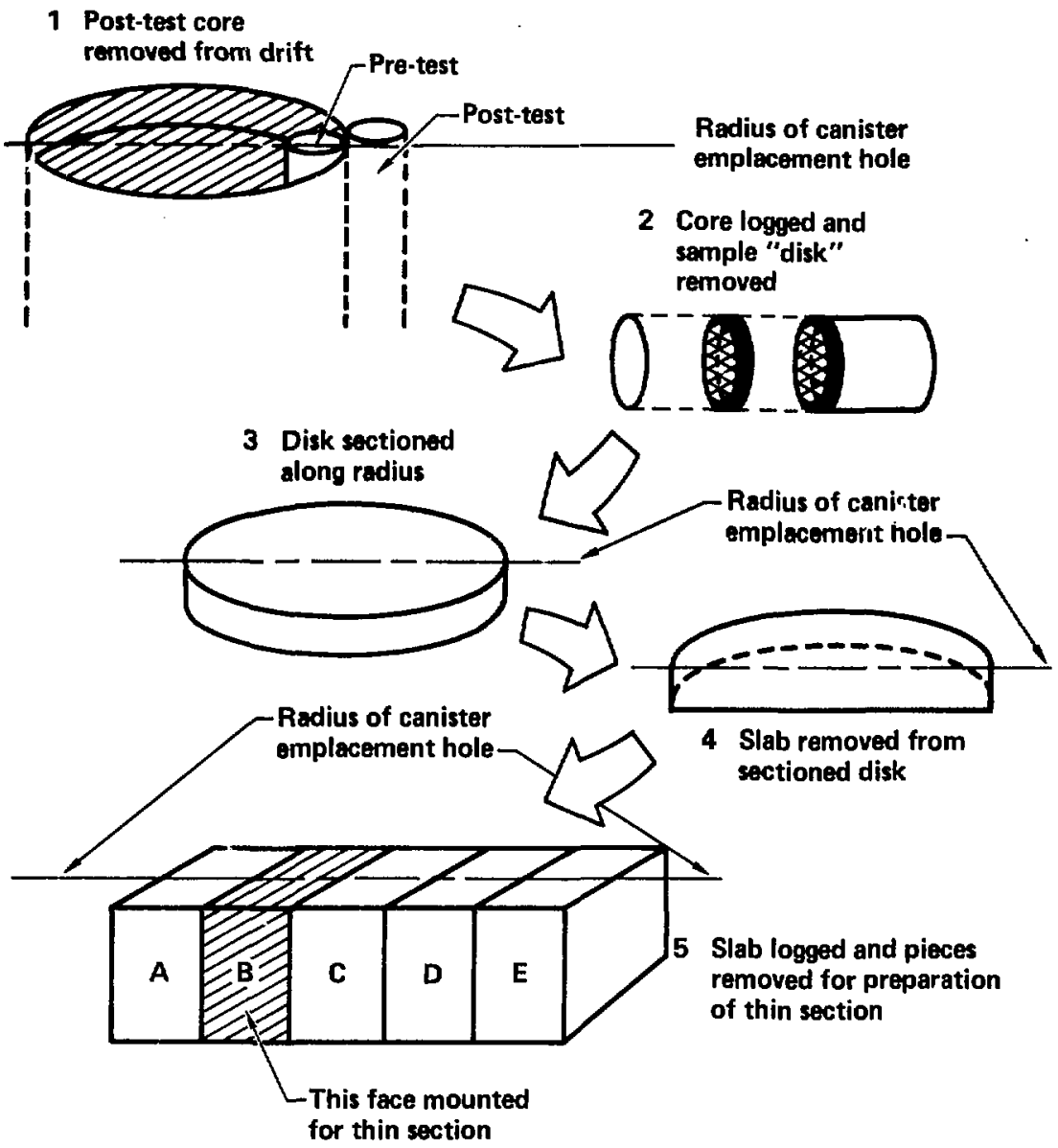

Figure 1. Location of post-test core samples with respect to the canister emplacement hole. Sample $A$ is closest to the canister, and all samples are taken along a radius of the canister emplacement hole.

with respect to the emplacement borehole, we cut a number a notches in these final slabs. The final polished thin sections provide a suite of samples oriented radially with respect to the source of heat and radiation. Therefore, the resulting data set can be evaluated with respect to the pre-test samples, as well as to the heat and radiation source in any particular hole.

\section{Analytical Techniques}

\section{Petrographic Analysis}

We examined all the thin sections in both reflected and transmitted light and noted the min- eral assemblages. Where necessary, we subdivided a section into fresh, altered, and vein assemblages (Appendix A). Then we stained samples from selected horizons for feldspars and ob- 
Table 1. Modal distribution (vol\%) of pre-4est samples."

\begin{tabular}{ccccccccccccc}
\hline $\begin{array}{c}\text { CCH } \\
\text { sample }\end{array}$ & Plag. & Ksp & Q & Bt & Mu & Chl & Czo-Ep & Ti & Ru & Mt & Py & Acc $^{r}$ \\
\hline 1 & 49.2 & 21.1 & 18.9 & 8.3 & 0.4 & 0.9 & 0.1 & 0.2 & 0 & 0.5 & 0.4 & 0 \\
2 & 49.6 & 18.0 & 17.6 & 12.3 & 0.2 & 0.7 & 0.2 & 0 & 0 & 0.7 & 0.6 & 0.1 \\
3 & 44.9 & 24.7 & 21.9 & 4.5 & 0.3 & 1.0 & 0.7 & 0.4 & 0 & 0.1 & 1.3 & 0.2 \\
5 & 47.1 & 20.6 & 23.9 & 3.9 & 0.3 & 1.1 & 0.3 & 0.3 & 0 & 0 & 2.5 & 0 \\
6 & 50.5 & 20.5 & 20.7 & 5.2 & 0.1 & 1.2 & 0.1 & 0.4 & 0 & 0.2 & 1.1 & 0 \\
7 & 44.1 & 21.2 & 23.7 & 4.7 & 0.6 & 1.8 & 0.6 & 0.7 & 0 & 0.6 & 1.8 & 0.2 \\
8 & 40.9 & 27.4 & 23.4 & 5.0 & 0 & 1.4 & 0.1 & 0.4 & 0 & 0 & 1.4 & 0 \\
10 & 52.7 & 18.7 & 22.1 & 3.8 & 0 & 1.0 & 0.5 & 0 & 0 & 0 & 1.2 & 0 \\
11 & 52.0 & 23.2 & 17.9 & 4.1 & 0.4 & 0.9 & 0.2 & 0.7 & 0 & 0 & 0.5 & 0.1 \\
13 & 50.5 & 21.6 & 19.2 & 5.3 & 0 & 1.9 & 0 & 0.6 & 0 & 0.7 & 0.2 & 0 \\
14 & 49.5 & 28.4 & 14.7 & 2.7 & 0.1 & 0.9 & 0.1 & 0.3 & 0 & 0 & 3.3 & 0 \\
16 & 42.3 & 22.1 & 22.5 & 7.4 & 0.1 & 1.8 & 0.5 & 1.3 & 0 & 0.5 & 1.5 & 0 \\
17 & 52.8 & 15.5 & 17.3 & 9.7 & 0.4 & 1.8 & 0 & 1.2 & 0 & 1.0 & 0.3 & 0 \\
& & & & & & & & & & & & \\
Avg & 48.2 & 21.8 & 20.3 & 5.9 & 0.2 & 1.3 & 0.3 & 0.9 & 0 & 0.3 & 1.2 & 0.2 \\
S.D. & 4.0 & 3.6 & 2.9 & 2.7 & 0.2 & 0.4 & 0.2 & 1.6 & 0 & 0.3 & 0.9 & 0.5 \\
\hline
\end{tabular}

"Phenocrysts greater than $4 \mathrm{~mm}$ in diameler omitted.

"Samples represent fresh material without linear features (i.e., veins, alteration, etc.).

'Allanite, apatite, and zircon.

tained 1000 point modes to determine the volume percentages of minerals. Although our previous study (Ryerson and Qualheim, 1983) included phenocrysts in the modal analyses, this procedure is problematical on a thin-section scale because it produces large variations in modal abundances depending on the presence or absence of phenocrysts. Thus, in this study we have not counted any phase greater than $4 \mathrm{~mm}$ in diameter, which prejudices our analysis toward groundmass mineralogy. We can argue the validity of this procedure by observing that natural hydrothermal alteration is concentrated in the groundmass and that any alteration produced by the SFT $-C$ is also likely to be concentrated there. To compare these results with those from pre-test $\mathrm{CCH}$ samples, we reanalyzed $13 \mathrm{CCH}$ samples using this revised procedure (Table 1 ).

\section{Microprobe Analyses}

As in our previous study (Ryerson and Qualheim, 1983), we obtained microprobe analyses in both automated and interactive modes, using a $2-\mu \mathrm{m} \times 2-\mu \mathrm{m}$ rastered beam at an accelerating potential of $15 \mathrm{kV}$ and a simple current (measured in a Faraday cup) of $15 \mathrm{nA}$. Automated mode allowed us to obtain analyses on a 300 -point grid on any particular thin section. The major objective of this type of analysis was to determine objectively the compositional distribution of the major phases, particularly the feldspars. Since the minor phases (less than $5 \mathrm{vol} \%$ ) are not well represented in the data set from automated analysis, we reanalyzed representative samples in an interactive mode, concentrating on minor and alteration phases.

\section{Post-Test Results}

In our previous report (Ryerson and Qualheim, 1983) we listed four types of mineralogical phenomena that could take place during the SFT-C:

1. Hydration reactions.

2. Dehydration reactions.

3. Precipitation of new phases from solutions

4. Cation exchange
Mineralogical evidence for the first three processes is the appearance of a new phase in the post-test samples. For instance, using thermodynamic analysis of Climax groundwater compositions, Isherwood et al. (1982) found that kaolinite and montmorillinite should form at the expense of plagioclase and K-feldspar. Also, an experimental study by Charles and Bayhursi (1980), in which a biotite grandiorite was reacted 
with distilled water, produced montmorillonite at 72 and $119^{\circ} \mathrm{C}$ and a variety of zeolites at higher temperatures $\left(310^{\circ} \mathrm{C}\right.$ maximum). Cation exchange processes can be determined by changes in mineral composition, but such processes are expected to be extremely sluggish in the temperature range of the SFT-C; the mineral chemistries below are presented as proof. As such, petrographic analysis of the post-test samples is expected to yield the most important data in evaluating the effects of SFT-C.

The petrographic data for each of the posttest samples studied is given in Appendix A. Since many of the samples are cut by veins with or without alteration haloes, we have chosen to subdivide them into unaltered $(/ \mathrm{U})$ and altered (/A). For instance, sample $\mathrm{CCH} 1-2.6 \mathrm{C}$ is cut by a vein containing pyrite, calcite, and clinozoisite; the area adjacent to the vein is designated $2.6 \mathrm{C} / \mathrm{A}$, and that region of sample $\mathrm{CCH} 1-2.6 \mathrm{C}$ unaffected by the hydrothermal solution once present in the vein is designated $2.6 \mathrm{C} / \mathrm{U}$. For each sample, we have further subdivided the mineralogy into primary mineralogy, alteration minerals on plagioclase and on biotite, and vein filling.

Plagioclase, K-feldspar, quartz, and biotite are listed among the primary phases. The primary igneous accessory phases - apatite, titanite, allanite, and zircon-have not been listed, but are ubiquitous and do not display any evidence of hydrothermal alteration.

As in the pre-test samples, plagioclase displays variable amounts of hydrothermal alteration. This alteration is most pronounced in haloes adjacent to calcite-bearing (fertile) veins and less pronounced adjacent to calcite-free (barren) veins. In both cases, these alteration haloes are overprinted by a ubiquitous deuteric alteration. Muscovite is the most common alteration phase on plagioclase occurring in every sample. Its ubiquity is due to its formation during the late-stage deuteric alteration, as well as that associated with hydrothermal fluids carried in veins. Clinozoisite and epidote can also be found in samples that experienced only deuteric alteration, but are more commonly found in alteration zones adjacent to veins. Calcite and $\mathrm{K}$-feldspar are restricted to the alteration zones adjacent to calcite-bearing veins that obviously acted as conduits for the transport of carbonate species to these alteration sites as part of the natural hydrothermal process.

Biotite displays a wider variety of alteration assemblages than does plagioclase and, in many cases, is totally replaced by secondary minerals. It is clear that these assemblages result from the dis- equilibrium overprinting of either a number of hydrothermal events or incomplete reequilibration to changing external conditions during a single event. The most common alteration style is the symplectic intergrowth of other sheet minerals (e.g., chlorite and muscovite). Chlorite is the most common phase, and its preserice on biotite is analogous to that of muscovite on plagioclase, occurring as both a product of deuteric alteration and hydrothermal alteration associated with veins. The distribution of epidote is similar to that of chlorite (epidote is absent in some samples, however), indicating that it was formed under similar conditions; chlorite and epidote is the most common subset of alteration phases on post-test samples, as it was on pre-test samples. With increasing intensity of alteration (e.g, adjacent to veins), muscovite, titanite, and pyrite are found on biotite. Rutile is found in the most intensely altered biotite, while calcite on biotite is found only adjacent to fertile veins. The alteration mineralogy records the depletion of potassium and, to a lesser extent, iron from the biotite sites coupled with an exrichment of calcium (released at the plagioclase site). The formation of rutile and titanite on the biotite sites reflects the low mobility of titanium relative to these other elements during hydrothermal alteration because these components are left as a residue on their original igneous sites.

The most important result of the post-test petrography is the absence of any new phases in the post-test samples and the identification of alteration textures identical to those of the pre-test samples studied. Hence, the conditions experienced during the SFT-C were not of sufficient duration or intensity for new phases to form or for pre-test minerals to be destroyed. It is interesting to note that results from post-test samples taken radial to heater holes in the north and south drifts of the Climax Mine yield conclusions identical to those presented here despite significantly higher temperatures in the heater drifts $\left(350^{\circ} \mathrm{C}\right.$ vs $\left.80^{\circ} \mathrm{C}\right)$ (Beiriger et al., 1984). As stated earlier, the natural hydrothermal event that affected the Climax Stock reached a maximum temperature of approximately $370^{\circ} \mathrm{C}$ at a pressure of $1 \mathrm{kbar}$. A similar temperature at 1 atm total pressure adjacent to the north and south heater drift holes would have caused the water to evaporate, drying the holes. In the absence of water, the $350^{\circ} \mathrm{C}$ conditions did not produce any mineralogical effect despite the instability of hydrous phases at these conditions. Thus, the continuous presence of hydrous phases must be attributed fo the sluggish kinetics of these dehydration reactions. 
The thin-section petrography establishes the absence of any pentrative chemical alteration due to the effects of the SFT-C. However, a film of fine-grained material was deposited on the wall of the canister hole subsequent to the removal of the PTC. To determine the nature of this material, we removed a sample from the surface of CEH1 for analysis by $x$-ray diffraction (XRD). The only phases identified in the XRD pattern were plagioclase, K-feldspar, quartz, and calcite. Plagioclase, quartz, and K-feldspar, which represent the major minerals in the quartz monzonite, are not expected to precipitate from aqueous solutions at the pressures and temperatures obtained during the SFT-C. Hence, we believe that this material is simply dust produced by drilling the initial canister hole or the post-test hole. Calcite is also present in the quartz monzonite, and its presence on this surface could similarly be attributed to drilling dust. However, in their analysis of Climax groundwater chemistry, Isherwood et al. (1982) concluded that calcite precipitation was a continuing process within the Stock. Since the rockwall surface was accessible to particulates, as well as fluids, we cannot eliminate the possibility that some of the observed calcite is a chemical precipitate.

\section{Modal Analyses}

Results of pre- and post-test modal analyses are presented in Tables 1 and 2, respectively. As stated earlier, our previous study of pre-test modal analyses included every type of mineral occurrence in the sample and, therefore, inhomogeneities due to the presence or absence of phenocrysts, alteration, and veins. For this study, we chose to exclude any phenocryst with a diameter greater than $4 \mathrm{~mm}$ in order to eliminate some of the scatter generated by primary igneous processes. Hence, a larger proportion of sample variability will be attributed to alteration processes, both hydrothermal and those produced by the SFT-C. In this connection, we employed the new procedure to select and analyze a suite of rela-

Table 2. Modal distribution (vol $\%)^{\mathrm{a}}$ of post-test samples.

\begin{tabular}{|c|c|c|c|c|c|c|c|c|c|c|c|c|}
\hline $\begin{array}{c}\mathrm{CCH} \\
\text { sample }\end{array}$ & Plag. & Ksp & $\mathrm{Q}$ & Bt & Mu & Chl & $C 20-E_{p}$ & $\mathrm{Ti}$ & $\mathrm{Ru}$ & $\mathrm{Mi}$ & Py & $A \mathrm{Ac}^{\mathrm{N}}$ \\
\hline $1-2.6 A$ & 48.2 & 17.8 & 21.0 & 3.2 & 4.9 & 1.3 & 1.6 & 0.8 & 0.1 & 0.1 & 1.0 & 0 \\
\hline $1-2.6 \mathrm{~B}$ & 49.2 & 17.5 & 21.5 & 5.3 & 1.4 & 1.2 & 2.8 & 0.8 & 0 & 0 & 0.3 & 0 \\
\hline $1-2.6 \mathrm{C}$ & 52.2 & 19.4 & 18.4 & 2.9 & 1.2 & 2.4 & 2.6 & 0.2 & 0 & 0.6 & 0.1 & 0 \\
\hline $1-2.6 \mathrm{D}$ & 56.4 & 19.1 & 16.0 & 4.1 & 0.9 & 1.0 & 1.0 & 0.2 & 0.1 & 0.5 & 0.7 & 0 \\
\hline $1-2.6 \mathrm{E}$ & 55.2 & 17.5 & 16.0 & 4.3 & 1.2 & 1.6 & 2.5 & 0.7 & 0.1 & 0.7 & 0.1 & 0.1 \\
\hline Avg. & 52.2 & 18.3 & 18.6 & 4.0 & 1.9 & 1.5 & 2.1 & 0.5 & 0.1 & 0.4 & 0.4 & 0 \\
\hline S.D. & 3.6 & 0.9 & 2.6 & 1.0 & 1.7 & 0.5 & 0.8 & 0.3 & 0.1 & 0.3 & 0.4 & 0 \\
\hline $1-15.0 \mathrm{~A}$ & 48.7 & 19.8 & 19.3 & 8.3 & 0.2 & 0.9 & 1.2 & 0.6 & 0 & 0.2 & 0.7 & 0.1 \\
\hline $1-15.0 B$ & 54.4 & 17.4 & 15.3 & 9.2 & 0.3 & 1.5 & 0.6 & 0.3 & 0 & 0 & 0.9 & 0.1 \\
\hline $1-15.0 \mathrm{C}$ & 559 & 18.0 & 17.9 & 3.9 & 0.3 & 1.1 & 0.9 & 1.0 & 0 & 0 & 1.0 & 0 \\
\hline $1-15.0 \mathrm{D}$ & 55.5 & 18.0 & 15.5 & 6.8 & 0.7 & 1.6 & 0.7 & 0.5 & 0.2 & 0 & 0.4 & 0.1 \\
\hline $1-15.0 \mathrm{E}$ & 58.1 & 19.4 & 16.6 & 2.7 & 0.1 & 1.3 & 0.5 & 0.5 & 0 & 0.1 & 0.6 & 0.1 \\
\hline Avg. & 54.5 & 18.5 & 16.9 & 6.2 & 0.3 & 1.3 & 0.8 & 0.6 & 0 & 0.1 & 0.7 & 0.1 \\
\hline S.D. & 3.5 & 1.0 & 1.7 & 2.8 & 0.2 & 0.3 & 0.3 & 0.3 & 0 & 0.1 & 0.2 & 0 \\
\hline 9-9.9A & 48.3 & 18.2 & 21.9 & 8.7 & 0 & 1.2 & 0.7 & 0.4 & 0 & 0.4 & 0.1 & 0.1 \\
\hline $9-9.9 B$ & 47.1 & 19.2 & 19.9 & 7.2 & 0.4 & 2.5 & 2.1 & 0.5 & 0.1 & 0.3 & 0.7 & 0 \\
\hline $9-9.9 \mathrm{C}$ & 50.4 & 17.1 & 22.9 & 3.2 & 0.6 & 1.4 & 1.8 & 0.8 & 0.5 & 0 & 1.3 & 0 \\
\hline 9-9.9D & 45.5 & 23.0 & 21.6 & 1.9 & 1.1 & 1.4 & 2.1 & 0.9 & 0 & 2.0 & 0.5 & 0 \\
\hline $9-9.9 \mathrm{E}$ & 53.4 & 18.3 & 17.7 & 3.9 & 0.3 & 1.7 & 2.5 & 0.6 & 0 & 1.3 & 0.3 & 0 \\
\hline Avg. & 48.9 & 19.2 & 20.8 & 5.0 & 0.5 & 1.6 & 1.8 & 0.6 & 0.1 & 0.8 & 0.6 & 0 \\
\hline S.D. & 3.1 & 2.3 & 2.0 & 2.9 & 0.4 & 0.5 & 0.7 & 0.2 & 0.2 & 0.8 & 0.5 & 0 \\
\hline Avg. & 51.6 & 18.5 & 18.5 & 4.3 & 0.4 & 1.4 & 1.1 & 0.6 & 0 & 0.1 & 0.6 & 0 \\
\hline S.D. & 2.8 & 0.5 & 2.0 & 1.4 & 1.1 & 0.2 & 0.9 & 0.1 & 0.1 & 0.5 & 0.2 & 0.1 \\
\hline
\end{tabular}

"Phenocrysts greater than $4 \mathrm{~mm}$ in diameter were not counted.

'Allanite, apatite, and zircon.

'All post-test data. 
tively fresh pre-test samples and then used them as a data base for comparison. Suites of five posttest samples taken radial to the canister hole (see Fig. 1) were selected from two horizons in $\mathrm{CCH} 1$ and from one horizon in $\mathrm{CCH} 9$ to investigate radial variations caused by fluctuations in temperature and radiation intensity, as well as intra- and interhole variability.

Comparison of the pre - and post-test modal abundances (Tables 1 and 2) indicates no statistically significant variation (based on $t$-test) between pre- and post-test samples within the resolution of the measurement technique (2 sigma after Van der Plas and Tobi, 1965). From this, we can conclude that the SFT-C has produced no overall variation in mineral abundance. This is in agreement with the petrographic observation that no new minerals formed during the SFT-C; in the absence of new phases, there is no mechanism by which to effect changes in mineral abundance. Further, the data indicate no obvious variations in abundance from hole to hole or with depth in a particular hole.

Significant modal variations do exist between samples taken at a particular depth. However, when plotted as a function of position away from the canister hole perimeter (Figs. 2 to 4 ), these

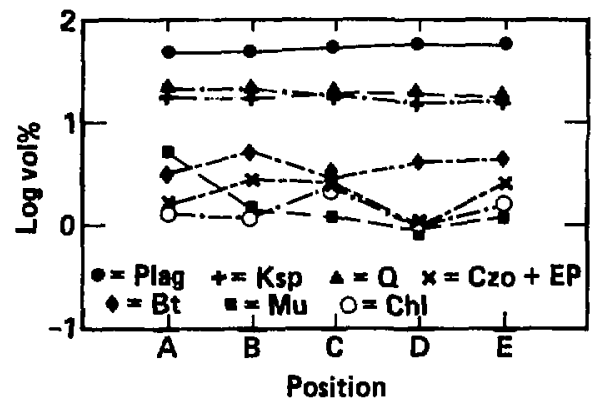

Figure 2. Modal data for CCH1-2.6 PT, showing vol\% of mineral vs position with respect to the CEH. variations show no distinctive radial pattern. Hence, we must attribute these variations in modal abundance to a combination of primary igneous processes and hydrothermal alteration.

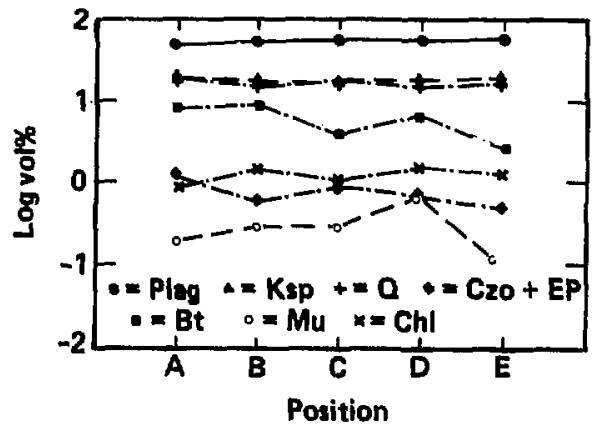

Figure 3. Modal data for CCH1-15.0 PT, showing vol\% of mineral vs position with respect to the CEH.

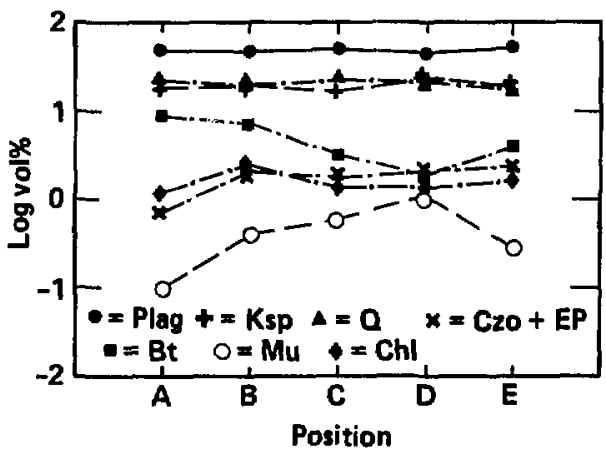

Figure 4. Modal data for CCH9-9.9 PT, showing vol\% of mineral vs position with respect to the CEH.

\section{Mineral Chemistry-Primary Phases}

\section{Feldspars}

Compositional data for both plagioclase and $K$-feldspar were obtained in the automated mode described earlier. The pre- and post-test results are tabulated in Tables 3 and 4, respectively. The pretest data were taken from relatively fresh samples similar to those from which the modal data were 
collected. Unlike the modal studies, however, this type of analysis could not avoid phenocrysts greater than $4 \mathrm{~mm}$ in diameter. The method of selecting samples was also similar to that used in selecting samples for modal analyses and allows changes in feldspar compositions to be evaluated with respect to depth, position within the canister drift, and position with respect to the heaters or spent fuel canisters.

Analysis of pre-test samples showed no significant intra- or interhole variation in either the plagicalase or K-feldapars. This is also true of the post-test data. A comparison of the pre- and posttest data indicates no statistically significant (based on t-test) change in the feldspar compositions as a result of the SFT $-C$. The average pretest plagioclase composition for the post-test samples is $A n_{32.61} \pm 2.11$ vs $A n_{31.87 \pm 1.44}$ and the average pre-test $\mathrm{K}$-feldspar composition is $\mathrm{Or}_{89.05} \pm 2.85$ vs Or $_{89.80} \pm 2.16$

There is also no variation in feldspar chemistry with respect to sample position relative to the canister hole (Figs. 5 to 7). A similar conclusion was reached for samples taken radial to a heater in the north drift, NHH10 (Fig. 8) (Beiriger et al., 1985).

\section{Biotite}

The biotite analyses were ubtained in an interactive mode. The data are presented in Appendix $B$, and the average of all analyses is given in Table 5. Although the pre- and post-test biotite data base is small in comparison with that for the

Table 3. Microprobe analyses of pre-test feldspars (numbers in parentheses are sample population sizes).

\begin{tabular}{|c|c|c|c|c|c|c|c|c|c|c|c|c|c|}
\hline $\begin{array}{l}\text { Hole No. } \\
\text { Depth }\end{array}$ & $\begin{array}{c}1 \\
16.75\end{array}$ & $\begin{array}{c}5 \\
10.05\end{array}$ & $\begin{array}{c}6 \\
8.3\end{array}$ & $\begin{array}{c}7 \\
10.3 \\
\end{array}$ & $\begin{array}{c}8 \\
9.8 \\
\end{array}$ & $\begin{array}{c}6 \\
13.3 \\
\end{array}$ & $\begin{array}{c}7 \\
9.15\end{array}$ & $\begin{array}{c}3 \\
9.4\end{array}$ & $\begin{array}{c}4 \\
3.1 \\
\end{array}$ & $\begin{array}{c}2 \\
7.6 \\
\end{array}$ & $\begin{array}{c}1 \\
14.8\end{array}$ & $\begin{array}{c}3 \\
4.1 \\
\end{array}$ & $\begin{array}{c}8 \\
9.3 \\
\end{array}$ \\
\hline & & & & & & \multicolumn{8}{|c|}{9} \\
\hline Plagioclase & 33.03 & 31.63 & 31.19 & 31.94 & 31.79 & 33.19 & 33.17 & 32.45 & 30.17 & 38.53 & 31.24 & 34.04 & 34.40 \\
\hline \multirow[t]{2}{*}{ S.D. } & 9.63 & 6.40 & 6.27 & 6.97 & 6.07 & 6.04 & 7.97 & 7.91 & 9.21 & 9.17 & 8.15 & 6.81 & 11.35 \\
\hline & (95) & (108) & (24) & (95) & (55) & (93) & (95) & (26) & (17) & $(108)$ & (56) & (119) & (103) \\
\hline K-feldsparb & 90.71 & 85.65 & 87.97 & 89.02 & 80.92 & 88.74 & 88.88 & 88.62 & 86.22 & 87.73 & 88.93 & 89.15 & 86.70 \\
\hline S.D. & 2.85 & 14,33 & 8.56 & 7.74 & 18.67 & 5.77 & 11.48 & 4.45 & 7.33 & 9.17 & 6.16 & 6.81 & 13.77 \\
\hline
\end{tabular}

Average of all pre-test analyses

Plagioclase" 32.61 \pm 2.11

K-feldspar $89.05 \pm 2.85$

"Mole \% anorthite.

"Mole \% K-feldspar.

Table 4. Microprobe analyses of post-test feldspars (numbers in parentheses are sample population sizes).

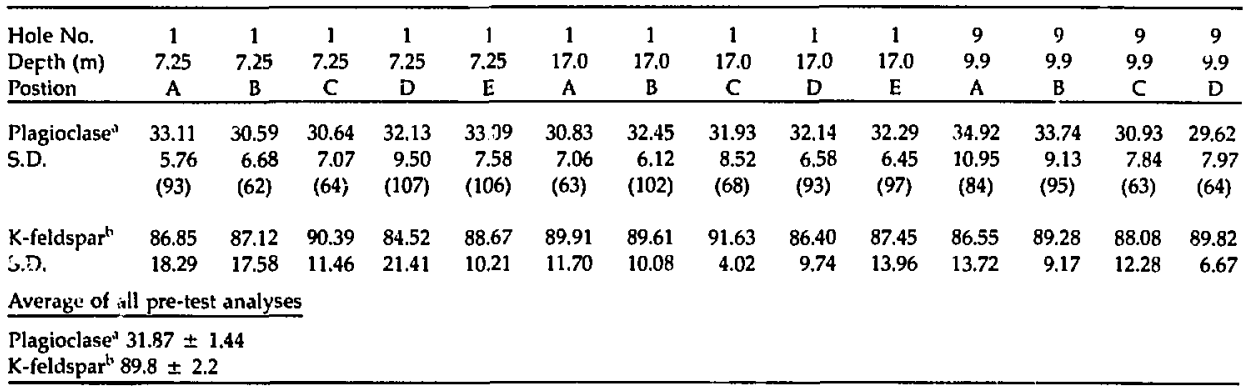




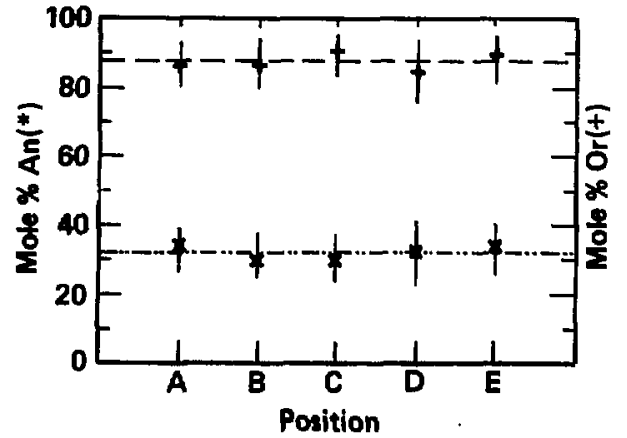

Figure 5. Feldepar compositions radially outward from CCH1-7.25 PT. The asterisk (") is mole \% anorthite in plagioclase, and the plus $(+)$ is mole $\%$ orthoclase in K-feldspar.

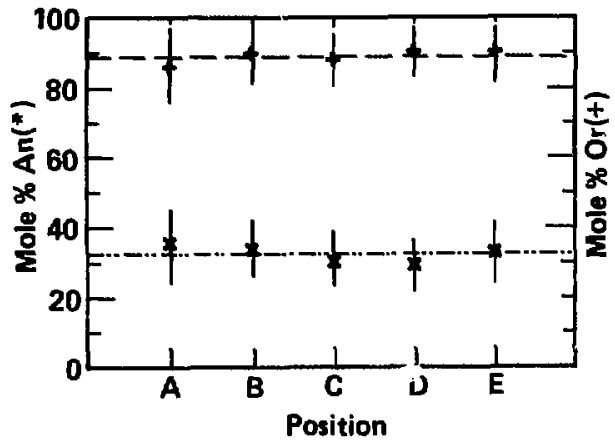

Fiğure 7. Feldopar compositions radially outward from CCH9-9.9 PT.

feldspars, the stoichiometry of the post-test biotite,

$\mathrm{K}_{2}\left[\mathrm{Ti}_{0.35}(\mathrm{Fe}, \mathrm{Mg})_{5.0} \mathrm{Al}_{0.15}\right]\left[\mathrm{Al}_{2,4} \mathrm{Si}_{5.6}\right] \mathrm{O}_{22}(\mathrm{OH})_{4}$.

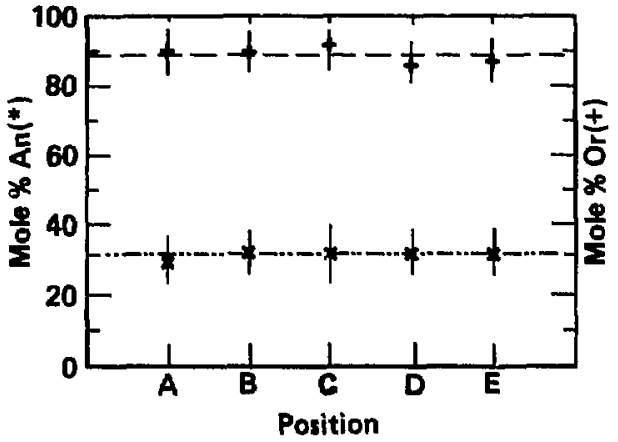

Figure 6. Feldspar compositions radially outward from CCH1-17.0 PT.

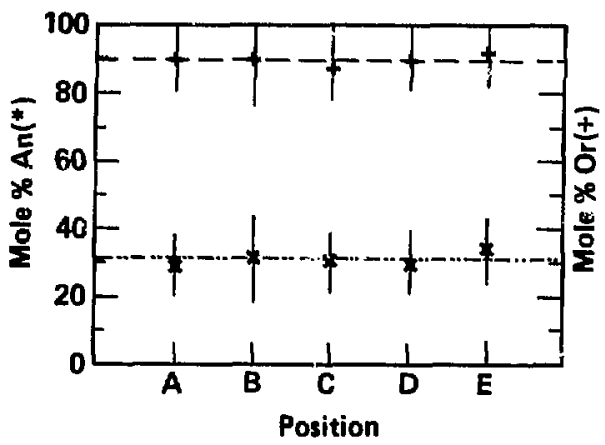

Figure 8. Feldspar compositions radially outward from NHH-10 PT (Beiriger et al., 1985).

is in good agreement with that of the pre-test biotite. More importantly, the range of post-lest biotite compositions lies totally within the range defined by the pre-test analyses (Fig. 9).

\section{Mineral Chemistry-Alteration Phases}

The muscovite analyses are presented in Appendix $B$, and the average muscovite composition is given in Table 5 . The stoichiometry of the average muscovite,

$\mathrm{K}_{2}\left[(\mathrm{Mg}, \mathrm{Fe})_{0.95} \mathrm{Al}_{3.2}\right] \mathrm{Si}_{6.5} \mathrm{Al}_{1.5} \mathrm{O}_{20}(\mathrm{OH})_{4}$ ， falls within the range defined by the pre-test analyses. As in the case of pre-test samples, the muscovites found on biotite are enriched in iron and magnesium compared to those on plagioclase, indicating that only local cation exchange equilibria was attained during hydrothermal alteration (Fig. 10). The compositional fields defined for the 
Table 5. Average micreprobe analyees (wt\%) of biotite, muscovite, chlorite, and clinozoisite-epidote (nunbers in parentheses are population sample sizes).

\begin{tabular}{lrrrr}
\hline Sample & Bt (M4) & \multicolumn{1}{c}{ Mu (57) } & \multicolumn{1}{c}{ Chl (46) } & Czo-Ep (24) \\
\hline $\mathrm{SiO}_{2}$ & $37.20 \pm 0.41^{2}$ & $47.64 \pm 0.88$ & $26.64 \pm 0.63$ & $38.11 \pm 0.59$ \\
$\mathrm{TiO}_{2}$ & $3.05 \pm 0.34$ & $0.34 \pm 0.33$ & $0.12 \pm 0.22$ & $0.28 \pm 0.34$ \\
$\mathrm{Al}_{2} \mathrm{O}_{3}$ & $14.82 \pm 0.29$ & $29.48 \pm 1.65$ & $20.09 \pm 0.83$ & $23.24 \pm 2.04$ \\
$\mathrm{FeO}$ & $19.31 \pm 0.47$ & $3.56 \pm 1.39$ & $23.33 \pm 2.36$ & $16.52 \pm 2.40$ \\
$\mathrm{MgO}$ & $11.38 \pm 0.38$ & $2.44 \pm 0.80$ & $0.63 \pm 1.55$ & $0.02 \pm 0.03$ \\
$\mathrm{MnO}$ & $0.62 \pm 0.07$ & $0.03 \pm 0.03$ & $0.73 \pm 0.27$ & $0.38 \pm 0.23$ \\
$\mathrm{CaO}$ & $0.02 \pm 0.02$ & $0.03 \pm 0.09$ & $0.03 \pm 0.03$ & $22.87 \pm 0.31$ \\
$\mathrm{Na}_{2} \mathrm{O}$ & $0.10 \pm 0.11$ & $0.15 \pm 0.09$ & $0.03 \pm 0.10$ & $0.00 \pm 0.01$ \\
$\mathrm{~K}_{2} \mathrm{O}$ & $9.74 \pm 0.19$ & $11.01 \pm 0.22$ & $0.03 \pm 0.08$ & $0.05 \pm 0.04$ \\
$\mathrm{P}_{2} \mathrm{O} \mathrm{O}_{3}$ & $0.03 \pm 0.03$ & $0.03 \pm 0.03$ & $0.03 \pm 0.03$ & $0.05 \pm 0.04$ \\
Total & $96.26 \pm 0.91$ & $94.72 \pm 1.04$ & $87.65 \pm 1.28$ & $97.49 \pm 1.12$ \\
\hline
\end{tabular}

"One standard deviation.

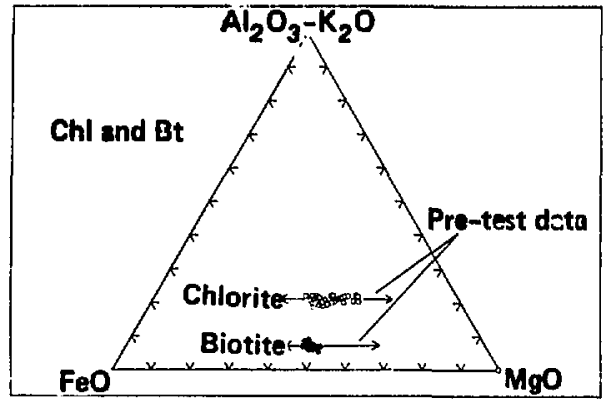

Figure 9. Compositions of post-test chlorites (o) and biotites $\left(^{*}\right)$ projected from quartz, muscovite, and water. The symbols give post-test data; the range of pre-test data is shown by the arrows.

two modes of occurrence of post-test muscovites correspond to those defined by the pre-test analyses (Fig. 10).

\section{Chlorite}

Chlorite is present solely as a symplectic intergrowith on biotite. The post-test chlorite analyses are given in Appendix $B$, and the average of all post-test analyses is given in Table 5. The stoichiometry of the post-test chlorites,

$(\mathrm{Fe}, \mathrm{Mg})_{9.25} \mathrm{Mn}_{0.13} \mathrm{Al}_{4.95} \mathrm{Si}_{5.59} \mathrm{O}_{20}(\mathrm{OH})_{16}$ ，

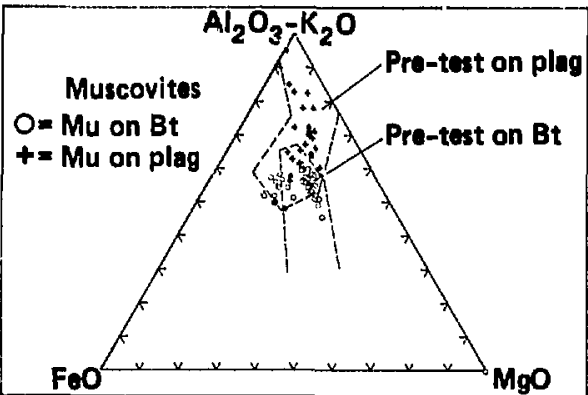

Figure 10. Compositions of post-test muscovites projected from quartz and water. The open circle (o) represents muscovite found on biotite, and the plus $(+)$ is muscovite found on plagioclase. The symbols give post-test data; the range of pre-test data is shown by the two outlined fields.

is also in good agreement with that of the pre-test analyses, and the range of post-test compositions falls totally within the range defined by the pretest samples. (Fig. 9).

\section{Clinozoisite and Epidote}

Clinozoisite and epidote are present as a complexly zoned solid solution on plagioclase (see Fig. 2, Ryerson and Qualheim, 1983) and as ironepidote on biotite. Compositional data are presented in Appendix B, and an average composition is given in Table 5 . The stoichiometry given 
by the $\mathrm{Ca}_{2}\left(\mathrm{Al}, \mathrm{Fe}^{+{ }^{\top}}\right)_{3} \mathrm{Si}_{3} \mathrm{O}_{12}(\mathrm{OH})$ of the post-test samples is in good agreement with that of the pretest analyses, and $\mathrm{Al} /(\mathrm{Al}-\mathrm{Fe})$ varies between 0.66 and 0.84 and is in good agreement with the range defined by the pre-test samples (Fig. 11).

Figure 11. Compositions of poat-test epidotes and clinozoisites projected from quartz and water. The symbols give post-tent data; the range of pre-test data is shown by the arrows.

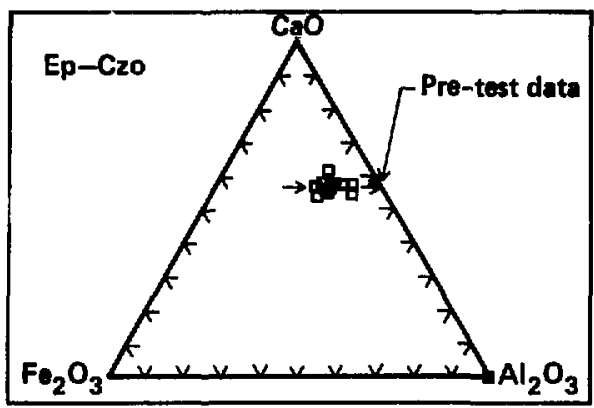

\section{Summary and Conclusions}

We analyzed the post-test samples to determine (1) mineral assemblages, (2) modal abundances, and (3) mineral chemistry. Samples were selected in a manner that allowed us to evaluate variations in these properties with respect to (1) depth in a particular canister hole, (2) position within the canister drift, (3) position with respect to the heat and radiation sources, and (4) pre-test results. In no case did we find any significant correlation between mineralogic properties and test variables. An analysis of samples from the north heater drift also yielded similar results despite much higher local temperatures (Beiriger et al, 1985).

Because we observed no significant eiffects, it follows that there was no difference between the effect of heat vs heat and radiation (CEH4 vs CEH1, CEH3, and CEH9). Further, we did not observe the possibility of enchanced aqueous dissolution in CEHI.

The current results are encouraging with respect to the eventual licensing of a repository in crystalline rock because they demonstrate that no gross changes in mineralogic properties occurred during SFT $-\mathrm{C}$. However, the SFT-C sampled a very limited range of external conditions and was not designed to assess the mineralogical response of granitic rocks to sustained low-temperature aqueous conditions. The possibility that some new minerals formed during the SFT $-\mathrm{C}$ cannot be precluded. In fact, the inherent instability of the feldspars under low-temperature aqueous conditions virtually guarantees the formation of clay minerals (c.f. Isherwood et al., 1982). Unfortunately, sluggish kinetics, the intermittent nature of aqueous conditions during the SFT-C, and the expected low abundances of these secondary phases prevents us from observing the resolution of this work. As such, laboratory studies of rockwater interactions for relevant granitic lithologies and external conditions are recommended.

\section{Acknowledgments}

We are grateful to B. Qualheim for logging the post-test core material and to $W$. Beiriger for his assistance in obtaining $x$-ray diffraction data. We are also grateful to W. Patrick, K. Knauss, and $L$. Younker for their comments on an earlier version of this report. 


\section{References}

Beiriger, J.M. W.B. Durham, and F.J. Ryernon, Physical and chemical changes to rock near electrically heated boreholes at Spent Fuel Test-Climax, Lawrence Livermore National Laboratory, Livermore, $\mathrm{CA}$ (to be published).

Carison, R.C., W.C. Patrick, D.G. Wilder, W.G. Brough, D.N. Montan, P.E. Harben, L.B. Ballou, and H.C. Heard, Spent Fuel Test-Climax: technical measurements interim report, FY 1980, Lawrence Livermore National Laboratory, Livermore, CA, UCRL-53064, 1980.

Charles, R.W. and G.K. Bayhuret, 9519 biotite granodiorite reacted in a temperature gradient, Los Alamos National Laboratory, Los Alamos, NM, LA-8566-MS, 1980.

Connolly, J.A., Hydrothermal alteration in the Climax Granite Stock at the Nevada Test Site, Arizona State University, AZ, unpublished M.S. thesis, 1981.

Isherwood, D. J. Harrax, and E. Raber, Characterization of Climax Granite ground water, Lawrence Livermore National Laboratory, Livermore, CA, UCRL-53309, 1982.

Maldonado, F., Summary of geology and physical properties of the Climax Stock, Nevada Test Site, U.S. Geological Survey, Washington, D.C., Open File Report 77-356, 1977.

Patrick, W.C., L.B. Ballou, T.R. Butkovich, R.C. Carlson, W.B. Durham, G.L. Hage, E.L. Majer, D.N. Montan, R.A. Nyholm, N.L. Rector, D.G. Wilder, and J.L. Yow, Jr., Spent Fuel Test-Climax: technical measurements interim report, fiscal year 1981, Lawrence Livermore National Laboratory, Livermore, CA, UCRL-53294-81, 1982.

Patrick, W.C., L.B. Ballou, T.R. Butkovich, R.C. Carleon, W.B. Durham, G.L. Hage, E.L. Majer, D.N. Montan, R.A. Nyholm, N.L. Rector, D.G. Wilder, and J.L. Yow, Jr., Spent Fuel Test-Climax: trchnical measurements interim report, fiscal year 1982, Lawrence Livermore National Laboratory, Livermore, CA. UCRL-53294-82, 1983.

Patrick, W., T.R. Butkovich, R.C. Carleon, W.B. Durham, H.C. Ganow, G.L. Hage, E.L. Majer, D.N. Montan, R.A. Nyholm, N.L. Rector, F.J. Ryernon, H. Weiss, and J.L. Yow, Jr., Spent Fuel TestClimax: technical measurements interim report, fiscal year 1983, Lawrence Livermore National Laboratory, Livermore, CA, UCRL-53294-83, 1984.

Ramspott, L.D., L.B. Ballou, R.C. Carlson, J.E. Duncan, W.C. Patrick, D.G. Wilder, W.G. Brough, and M.C. Mayr, Technical concept for a test of geological storage of spent reactor fuel in the Climax Granite, Nezada Test Site, Lawrence Livermore National Laboratory, Livermore, CA, UCRL-52796, 1979.

Ryerson, F.J., and B.J. Qualheim, Mineralogical and petrological investigation of pre-test core samples from the Spent Fuel Test-Climax, Lawrence Livermore National Laboratory, Livermore, CA, UCID19976, 1983.

Van der Plas, L., and A.C. Tobi, "A chart for judging the reliability of point counting results," Am. J. Sci. 263, 87-90, 1965. 